\title{
IDENTIFIKASI BANJIR DENGAN METODE INDEKS KEBASAHAN DI KABUPATEN BANGGAI LAUT
}

\section{FLOOD IDENTIFICATION WITH WETNESS INDEX METHOD IN BANGGAI LAUT DISTRICT}

\author{
Ahmad Pratama Putra, Wisyanto ${ }^{1}$
}

\begin{abstract}
ABSTRAK: Peta Indeks bahaya banjir yang dibuat oleh BNPB adalah berskala nasional. Ini merupakan tantangan bagi BPBD Kabupaten Banggai Laut untuk mengidentifikasi lebih detil daerah banjir dengan skala kabupaten berdasarkan keterbatasan data pendukung yang biasanya terjadi di daerah kepulauan ini. Penelitian ini bertujuan untuk mengidentifikasi daerah-daerah potensi banjir di Kabupaten Banggai Laut dengan metode indeks kebasahan dan melakukan validasi keakuratan metode dengan observasi lapangan. Hasilnya, Kabupaten Banggai Laut tidak memiliki potensi bahaya banjir kelas tinggi. Metode indeks kebasahan untuk identifikasi daerah banjir cukup akurat untuk diterapkan di daerah dengan karakteristik fisik wilayah yang banyak keseragaman dan data ketersediaan sangat terbatas.
\end{abstract}

Kata kunci: Indeks Kebasahan, Banjir, Kabupaten Banggai Laut.

ABSTRACT: Flood Index Map created by BNPB is on a national scale. It is a challenge for BPBD of Banggai Laut District to detailing the flood area with district scale based on the limitations of the data supporting in this archipelago. This study intends to identify areas of potential flooding in Banggai Laut District with wetness index method and validate the accuracy of the method with field observations. The result showed that Banggai Laut District has no high class potential danger of flooding. Wetness index method for the identification of flooded areas is accurate enough to be applied to the area with the physical characteristics of the region that a lot uniformity and data availability is very limited.

Keywords: Wetness Index, Flood, Banggai Laut District.

\section{PENDAHULUAN}

\subsection{Deskripsi Permasalahan}

Secara histori data peta rawan bencana banjir Indonesia yang diperoleh dari BNPB, pada tahun 2009 dapat diamati pada Gambar

1 PTRRB, BPPT, Geostech, Gedung 820, Puspiptek, Serpong. email:ap.putra86@gmail.com
1, bahwa Kabupaten Banggai Laut memiliki indeks rawan bencana banjir rendah. Hal ini menunjukkan bahwa Kabupaten Banggai Laut memiliki potensi ancaman yang kecil pada tahun 2009.

Sementara itu, dari data peta rawan bencana banjir Indonesia tahun 2010 (Gambar 2), Kabupaten Banggai Laut mulai terlihat variasi warna yaitu hijau kemudian kuning agak kemerahan. Hal ini menunjukkan bahwa Kabupaten Banggai Laut pada umumnya 
memiliki ancaman banjir rendah dan sebagian daerah memiliki ancaman banjir sedang dan sebagian kecil lagi memiliki ancaman banjir tinggi.

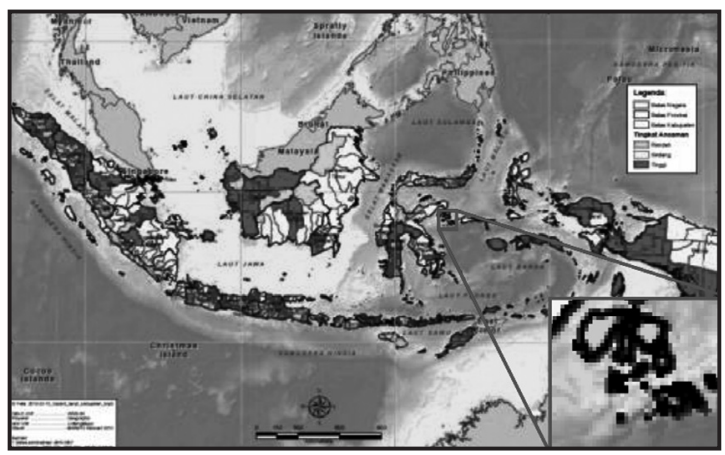

Gambar 1. Peta indeks rawan bencana banjir Indonesia tahun 2009.

(Sumber : Geospasial BNPB)

Pada data rawan bencana banjir Indonesia tahun 2011 (Gambar 3), Kabupaten Banggai Laut memiliki indeks warna hijau. Hal ini dapat diidentifikasi bahwa pada tahun 2011 Kabupaten Banggai Laut diprediksi memiliki potensi ancaman banjir rendah.

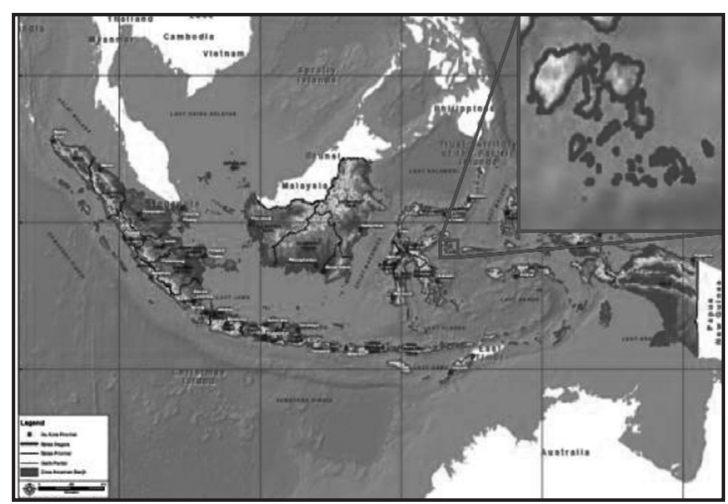

Gambar 2. Peta indeks rawan bencana banjir Indonesia tahun 2010.

(Sumber : Geospasial BNPB)

Jadi, data sekunder berupa peta rawan bencana banjir Indonesia yang dikeluarkan oleh instansi yang sama pada tiga tahun yang berbeda secara umum menjelaskan bahwa Kabupaten Banggai Laut memiliki ancaman potensi bahaya banjir yang rendah.

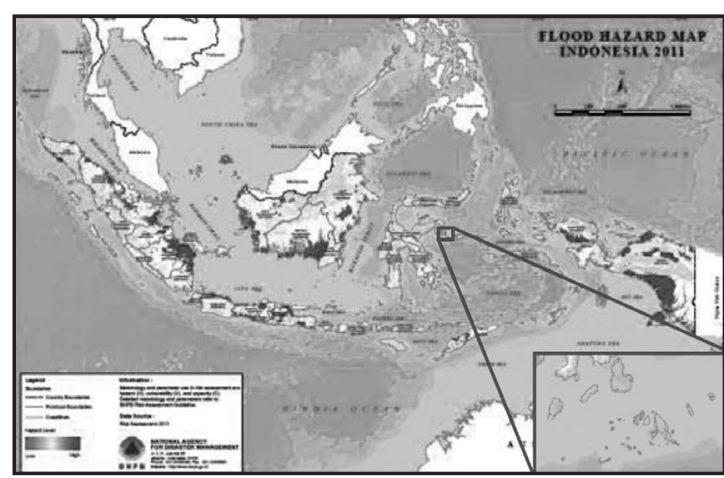

Gambar 3. Peta indeks rawan bencana banjir Indonesia tahun 2011.

(Sumber : Geospasial BNPB)

Namun, pada fakta kejadian banjir yang dicatat oleh Badan Penanggulangan Bencana Daerah (BPBD) Kabupaten Banggai Laut dari tahun 2011 sampai dengan 2015 terdapat beberapa kejadian banjir yang pernah terjadi di Kabupaten Banggai Laut yaitu:

- Desa Lompio; 20 rumah terendam.

- Desa Gonggong; 7 rumah terendam.

- Desa Badumpayan; 10 rumah terendam.

- Desa Alasan, Labobo; 43 jiwa mengungsi.

- Desa Lipulalango, Labobo; 20 rumah terendam dan 5 rumah rusak berat.

Peta indeks rawan bencana yang dibuat BNPB adalah dalam skala nasional. Hal ini menjadi tantangan bagi BPBD Kabupaten Banggai Laut untuk mendetailkan area banjir dengan skala kabupaten dengan keterbatasan data-data penunjang wilayah kepualauan seperti ini.

\subsection{Tujuan}

Maksud dari kajian identifikasi potensi banjir Kabupaten Banggai Laut dengan metode indeks kebasahan ini adalah menyediakan informasi mengenai potensi bahaya banjir di Kabupaten Banggai Laut dan menguji keakuratan metode yang dipakai dalam kajian ini. Hasil dari kajian ini juga diharapkan akan menjadi pedoman dan 
acuan bagi BPBD Kabupaten Banggai Laut dalam mengkoordinasikan semua rencana penyusunan kebijakan dan kegiatan terkait program mitigasi bencana banjir yang dilakukan oleh BPBD Kabupaten Banggai Laut secara lebih terarah, terpadu dan menyeluruh serta terkoordinasi baik dengan instansiinstansi lain.

\section{METODOLOGI}

\subsection{Lokasi dan Waktu Kajian}

Lokasi kajian ini adalah di daerah Kepulauan Kabupaten Banggai Laut dan dilaksanakan selama enam bulan pada tahun 2016. Kabupaten Banggai Laut yang terdiri dari gugusan pulau-pulau, yaitu terdiri dari empat pulau sedang dan 286 pulau kecil. Gugusan pulau ini terletak pada $1^{\circ} 26^{\prime} 0^{\prime \prime} \mathrm{LS}-2^{\circ} 18^{\prime} 0^{\prime \prime} \mathrm{LS}$ dan $123^{\circ} 0^{\prime} 0^{\prime \prime} B T-124^{\circ} 0^{\prime} 0^{\prime \prime}$ BT. Kabupaten Banggai Laut, memiliki batas wilayah sebagai berikut (Gambar 4) :

- Sebelah Utara berbatasan dengan Laut Maluku, Selat Kalumbatan dan Selat Bangkurung.

- Sebelah Timur berbatasan dengan Laut Maluku.

- Sebelah Selatan berbatasan dengan Laut Banda.

- Sebelah Barat berbatasan dengan Teluk Tolo.

Berdasarkan Draft RTRW Kabupaten Banggai Laut 2015-2035, secara administratif Kabupaten Banggai Laut terbagi atas 7 wilayah kecamatan, 3 Kelurahan dan 63 Desa. Luas wilayah Kabupaten Banggai Laut lebih kurang $12.882,45 \mathrm{~km}^{2}$ yang terdiri dari luas daratan $725,67 \mathrm{~km}^{2}$ atau sekitar $5,63 \%$ dari luas keseluruhan dan luas laut 12.156,78 km² atau sekitar 94,37\% dari luas keseluruhan.

Kabupaten Banggai Laut merupakan salah satu di antara 13 kabupaten/kota di Provinsi Sulawesi Tengah dengan Ibu Kota berkedudukan di Kota Banggai di bentuk berdasarkan Undang-undang Republik Indonesia Nomor 5 Tahun 2013, dimana sebelumnya merupakan bagian dari Kabupaten Bangai Kepulauan. Berada pada kawasan Teluk Tolo yang mempunyai potensi Sumber Daya Alam (SDA) yang sangat potensial untuk dikembangkan di Kawasan Timur Indonesia (KTI).

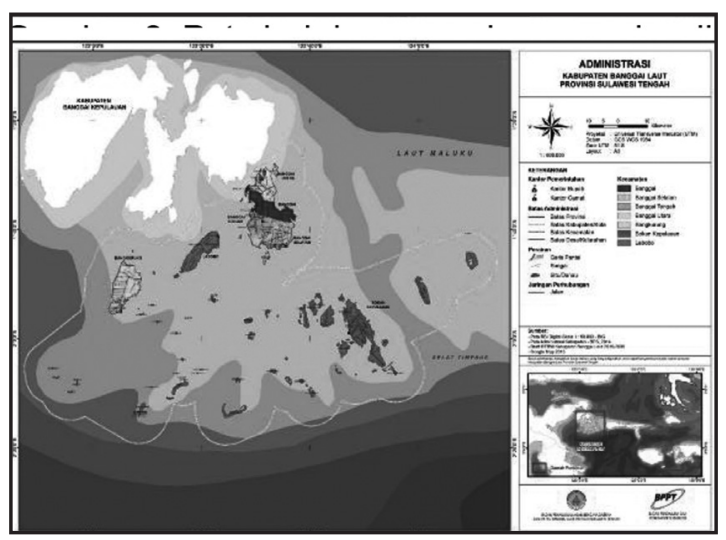

Gambar 4. Peta Administrasi Kab. Banggai Laut, Sulawesi Tengah.

(Sumber : Laporan Kegiatan Perencanaan Pengelolaan SDA Daerah Tertinggal, BPPT).

Kabupaten Banggai Laut terdiri dari 4 (empat) gugus kepulauan yang letaknya berdekatan juga terdapat pulau-pulau kecil baik yang berpenghuni maupun tidak berpenghuni. Gugusan pulau-pulau tersebut dikelompokkan dalam empat klaster pengembangan sebagaimana diuraikan berikut ini:

1. Klaster Pulau Banggai dan Pulau kecil sekitarnya, meliputi: wilayah Kecamatan Banggai, Kecamatan Banggai Utara, Kecamatan Banggai Tengah dan Kecamatan Banggai Selatan dengan pusat pengembangan di Kecamatan Banggai.

2. Klaster Pulau Bangkurung dan Pulau kecil sekitarnya, meliputi keseluruhan wilayah Kecamatan Bangkurung dengan pusat pengembangan di Lantibung.

3. Klaster Pulau Labobo dan Pulau kecil sekitarnya, meliputi keseluruhan wilayah Kecamatan Labobo dengan pusat pengembangan di Mansalean. 
4. Klaster Kepulauan Bokan, meliputi keseluruhan wilayah Kecamatan Bokan Kepulauan dengan pusat pengembangan di Bungin.

\subsection{Jenis data}

Untuk mengetahui pontensi banjir pada suatu wilayah, unit analisis yang digunakan adalah dalam satuan DAS (Daerah Aliran Sungai), sehingga diperlukan suatu pemodelan spasial hidrologi dalam menentukan batasbatas DAS tersebut. DAS adalah satuan wilayah berupa sistem lahan dengan tutupan vegetasinya yang dibatasi oleh batas-batas topografi alami (seperti punggung-punggung bukit) yang menerima curah hujan sebagai masukan DAS, mengumpulkan dan menyimpan air, sedimen dan unsur hara lain, serta mengalirkannya melalui anak-anak sungai untuk akhirnya keluar melalui satu sungai utama ke laut atau ke danau (Pawitan, 2004).

Jenis data yang diperlukan untuk melakukan pemodelan guna mengetahui potensi banjir diantaranya adalah sebagai berikut:

- DEM (Digital Elevation Model), menggunakan DEM dari SRTM (Shuttle Radar Topographic Mission) yang memiliki resolusi $30 \mathrm{~m}$.

- Kelerengan.

- Tutupan lahan.

- Jalur dan arah aliran permukaan.

- Curah hujan, sumber: Badan Meteorologi, Klimatologi dan Geofisika.

- Histori banjir dari BPBD Kabupaten Banggai Laut.

- Kontur.

- Daerah Aliran Sungai.

- Data survei lapangan.

\subsection{Indeks Kebasahan}

Metode Index Kebasahan TWI (Topographic Wetness Index) adalah metode untuk memodelkan zona rawan banjir dengan menggunakan data Digital Elevation Model (DEM). Model data raster yang digunakan lebih sesuai untuk memodelkan zona rawan banjir, terutama dalam memahami pola aliran dari data topografis yang ada (El-Sheimy, N. 1999).

Model ini menggunakan DEM yang diturunkan menjadi akumulasi aliran (flow accumulation), batas DAS (Watershed), arah aliran (flow direction) dan tipe/ordo sungai (stream), dengan menggunakan Watershed Delineation Tools (WDT) pada Analyst Tools program Arc GIS dapat dihitung zona banjir (Prahasta, 2008).

Penyusunan informasi spasial bencana banjir ditempuh melalui pemodelan spasial Daerah Aliran Sungai. Adapun tahapan yang dilakukan pada tahap ini adalah dititikberatkan kepada penurunan algoritma tentang hidrologi dan geomorfologi yang berupa:

- Sink; merupakan bagian yang sering terdapat pada lembah yang sempit di mana lebar lembah tersebut lebih kecil dari ukuran sel.

- $\quad$ Flow Direction; merupakan arah di mana air mengalir ke luar dari sebuah sel DEM (Meijerink et al., 1994). Seperti terlihat pada Gambar 5.

- Flow Accumulation; untuk mengetahui ke mana arah air akan mengalir, sehingga dapat digambarkan daerah mana yang mempunyai kelebihan air yang mengalir melaluinya dibandingkan dengan daerah lainnya. Seperti terlihat pada Gambar 6.

- Stream Channel dan Stream Link. Seperti terlihat pada Gambar 7.

- Pembuatan Watershed. Seperti terlihat pada Gambar 8.

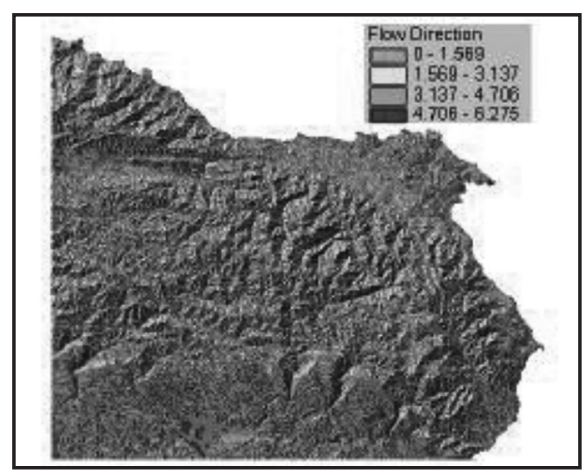

Gambar 5. Hasil flow direction dari data DEM. 


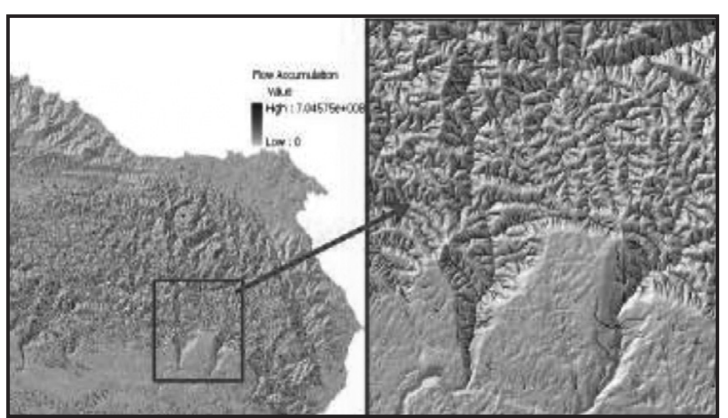

Gambar 6. Hasil flow Accumulation dari data DEM.

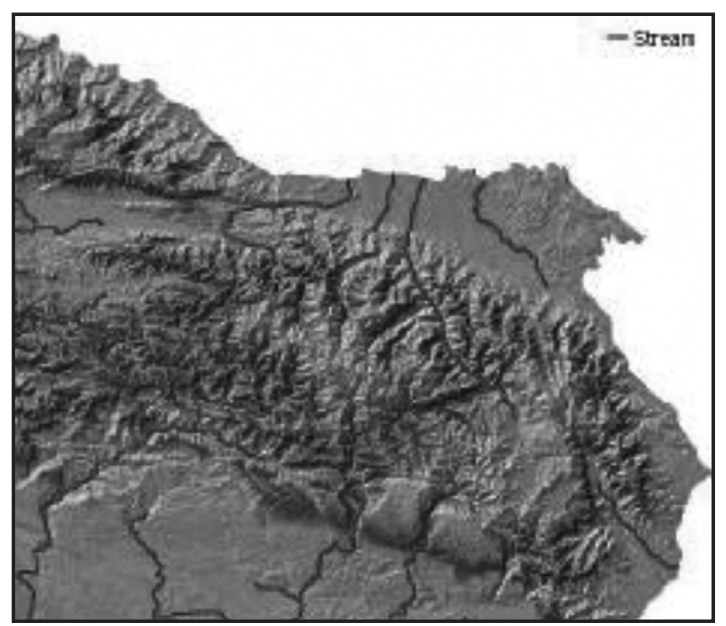

Gambar 7. Hasil stream channel dan stream link dari data DEM.

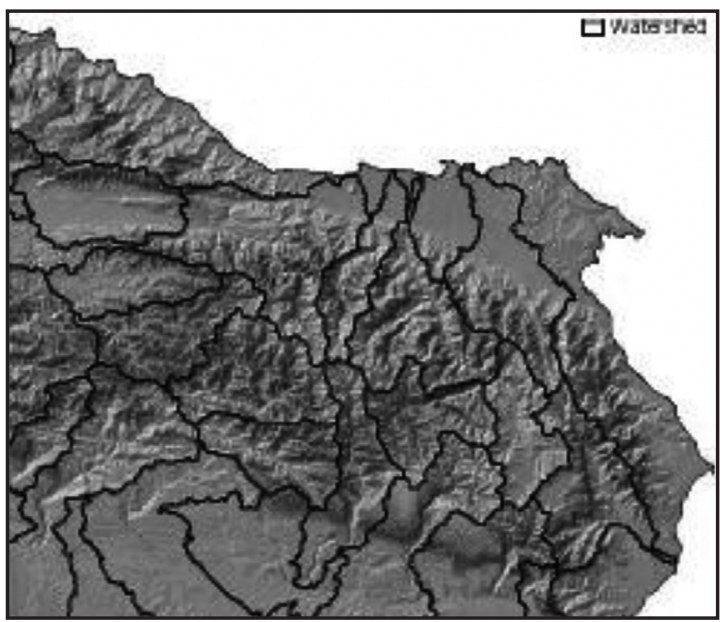

Gambar 8. Hasil watershed dari data DEM.
Selanjutnya, penentuan area potensi banjir yang didahului dengan penentuan aliran permukaan. Persamaan ketersediaan air untuk limpasan atau aliran permukaan digunakan untuk menghitung jumlah air yang tersedia bagi limpasan permukaan berdasarkan kejadian hujan tertentu pada tipe atau kondisi tanah dan jenis penutupan lahan di suatu lokasi. Dengan informasi ini, jumlah air yang tersedia untuk limpasan pada setiap sel dalam DAS dapat diduga, dan kemudian diakumulasikan untuk suatu permukaan arah aliran. Proses penurunan model hidrologis tersebut diperlihatkan Gambar 9.

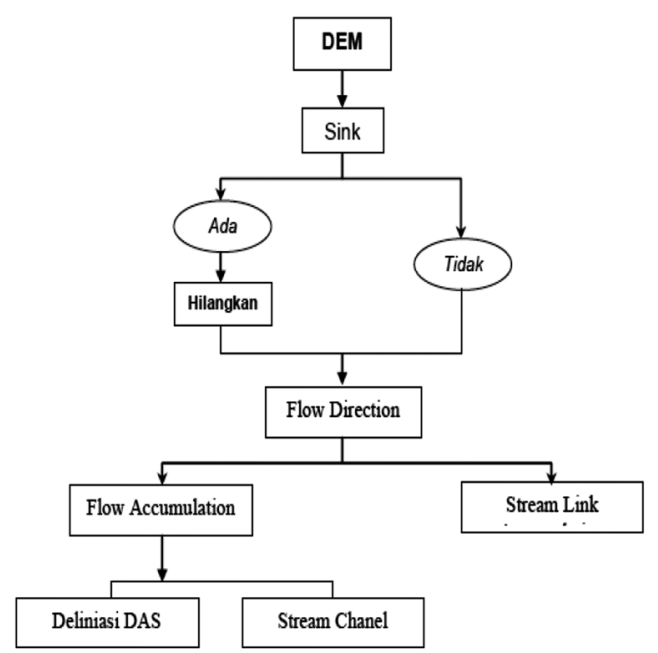

Gambar 9. Bagan alir penurunan model hidrologis.

Menurut Putra E. H. (2007), Wetness Index (WI) adalah indeks kebasahan yang dapat digunakan sebagai indikator dari suatu kawasan yang mempunyai potensi banjir. Indeks ini diturunkan dari peubah-peubah permukaan, sehingga untuk mengetahui jumlah limpasan air yang tersedia ataupun tinggi suatu genangan air dalam tiap sel atau area maka diperlukan informasi dari perhitungan limpasan permukaan.

Wetness Index dihitung dengan persamaan berikut :

$W I=\ln (A s / \tan B)$ 
dimana :

As= Luas Area, jika dilakukan pendekatan raster maka As adalah Akumulasi Ketersediaan Air Untuk Limpasan / flow accumulation.

$\mathrm{B}=$ Kemiringan lahan (dalam derajat).

Peta Potensi Banjir diperoleh berdasarkan hasil re-klasifikasi nilai dari peta Wetness Index tersebut di atas. Klasifikasi nilai Wetness Index dibuat dengan memperhatikan beberapa parameter agar lebih akurat. Parameter tersebut diantaranya histori banjir di Kabupaten Banggai Laut, kelerengan, tutupan lahan, kelas lereng, kontur, daerah aliran sungai, dan curah hujan. Sehingga klasifikasi yang digunakan adalah yang menggambarkan tingkat potensi banjir dan dibagi ke dalam 3 (tiga) kelas, yaitu:

- $\mathrm{WI}<10$ = Tidak Berpotensi (Aman)

- $10<\mathrm{WI}<12=$ Potensi Rendah

- $12<\mathrm{WI}<23=$ Potensi Sedang

\subsection{Verifikasi Hasil}

Verifikasi hasil dilakukan dengan pengamatan lapangan dengan sampel mewakili klaster pulau di Kabupaten Banggai Laut. Verifikasi juga dilakukan dengan data histori kejadian banjir baik dari data sekunder BPBD Kabupaten Banggai Laut maupun dari hasil diskusi dengan warga sekitar.

\section{HASIL DAN PEMBAHASAN}

Banjir merupakan $\begin{array}{r}\text { bencana } \\ \text { faktor }\end{array}$
hidrometeorologis, sehingga
meteorologis juga menjadi yang dominan
dalam mengidentifikasi wilayah bahaya
banjir. Pada kabupaten ini, berdasarkan
data BMKG, curah hujan yang tercatat
besarannya adalah $1400-1800$ mm/tahun.
Jumlah ini adalah sangat kecil untuk ukuran
curah hujan tahunan. Sehingga dalam
proses perhitungan analisis wilayah banjir
pada kajian ini, variabel curah hujan tidak
memiliki peran signifikan.

Variabel penggunaan lahan juga mempunyai kontribusi terhadap terjadinya banjir pada suatu wilayah. Penggunaan lahan akan menyebabkan perbedaan infiltrasi dan run off (air limpasan permukaan) dari suatu area dengan area lainnya. Dalam perhitungan debit banjir, variasi penggunaan lahan akan mempengaruhi perhitungan karena akan menunjukkan variasi koefisien (C) yang beragam. Di Kabupaten Banggai Laut ini profil penggunaan lahan lebih banyak didominasi oleh hutan dan area penggunaan lain (APL). Untuk APL, variasinya juga banyak untuk perkebunan dan pertanian. Sehingga boleh dikatakan penggunaan lahan di Kabupaten Banggai Laut ini relatif seragam, yaitu penggunaan lahan yang memiliki daya infiltrasi relatif tinggi dan run off yang relatif kecil.

Variasi jenis batuan yang tidak terlalu beragam dan didominasi oleh batuan gamping yang membuat peluang terjadinya banjir di wilayah kabupaten ini diduga semakin kecil. Sifat batuan gamping memiliki tingkat infiltrasi terhadap air hujan yang tinggi sehingga relatif membuat runoff (aliran limpasan permukaan) semakin sedikit.

Pada kajian ini, perhitungan identifikasi wilayah banjir di dominasi oleh topografi. Variasi topografi dan kelerengan adalah menjadi faktor alami utama yang menyebabkan potensi banjir. Walaupun, penataan drainase yang kurang baik pada areal permukiman juga menjadi penyebab banjir yang pernah terjadi di wilayah kabupaten ini. Morfologi Kabupaten Banggai Laut dapat dilihat pada gambar 10.

Sebagaimana kebanyakan area kepulauan, Kabupaten Banggai Laut ini didominasi oleh daerah dataran rendah serta slope (kemiringan lereng) yang relatif landai dan cekungan-cekungan yang dapat menjadi tempat akumulasi aliran air bermuara. Selain di cekungan-cekungan, potensi banjir juga banyak terjadi di pinggir pantai akibat rob.

Karena morfologi diduga memainkan peranan penting pada penyebab potensi banjir di kabupaten ini, maka analisis spasial identifikasi wilayah banjir pada kajian ini 
menggunakan metode TWI atau topographic wetness index (indeks kebasahan topografi). Dengan sumber data dari SRTM (Shuttle Radar Topograpic Map) 1 arc-second (30 meter) maka diolah indeks kebasahan sebagaimana yang telah dijelaskan dalam bab metodologi.

Hasil dari TWI ini adalah berupa polapola aliran yang menegaskan bahwa jika ada air hujan yang jatuh di area tersebut dan atau ada air limpasan sungai dari area lain yang akan melalui area tersebut, maka air tersebut akan mengalir pada pola-pola aliran yang terbentuk hasil analisis TWI ini. Jika aliranaliran itu berkumpul pada suatu area tertentu dan stagnan, maka area itu diduga akan terjadi kumpulan air berlebih yang melebihi kapasitas tampung area tersebut. Peristiwa inilah yang disebut dengan banjir.

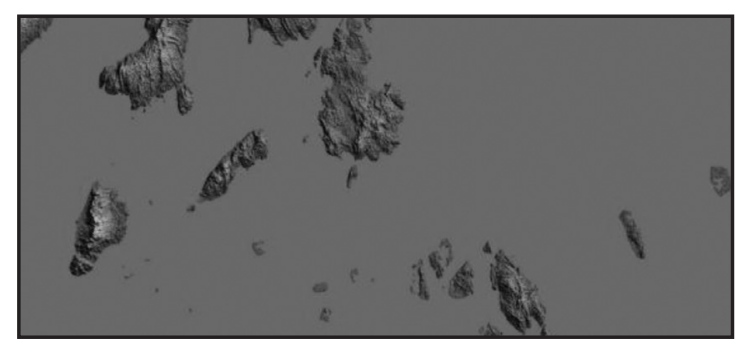

Gambar 10. Morfologi Kabupaten Banggai Laut.

(Sumber: SRTM 30 m).

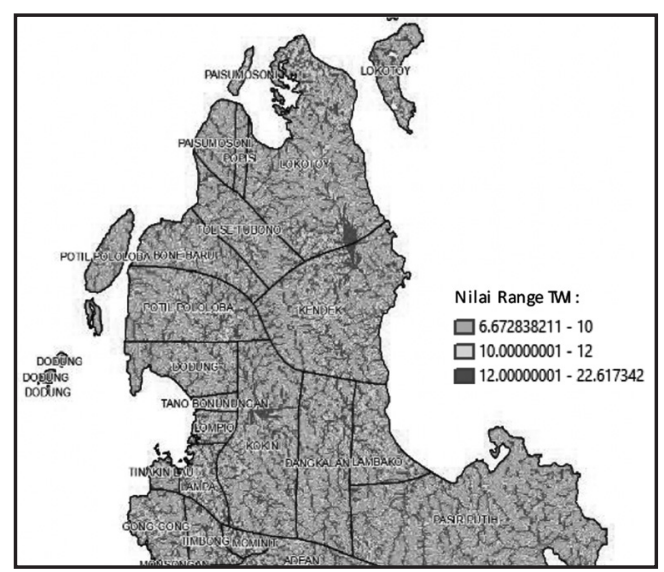

Gambar 11. Hasil index kebasahan Pulau Banggai.

(Sumber: Pengolahan data, 2016).
Gambar 11 adalah contoh hasil dari indeks kebasahan (TWI) di Pulau Banggai. Guratan-guratan warna merah menunjukkan pola-pola aliran baik ada atau tidak ada air. Pada Desa Kokini dan Desa Lokotoy, dapat dilihat ada kumpulan warna merah hasil identifikasi indeks kebasahan. Hal ini menunjukkan bahwa kumpulan warna merah tersebut adalah area terendah dari area sekitarnya, tempat muaranya aliran-aliran. Area tersebut yang dalam kajian ini diidentifikasi memiliki potensi banjir.

Dalam proses simplifikasi dengan metode interpretasi manual (digitasi on screen), maka hasil TWI disesuaikan dengan parameter-parameter lain agar hasil interpretasi lebih akurat. Parameter tersebut diantaranya kelerengan, tutupan lahan, kelas lereng, kontur, daerah aliran sungai, dan curah hujan. Klasifikasi juga didasarkan pada aplikasi TWI pada area-area banjir lain. Sehingga klasifikasi yang digunakan adalah yang menggambarkan tingkat potensi banjir dan dibagi ke dalam 3 (tiga) kelas pada Kabupaten Banggai Laut ini, yaitu:

- $\mathrm{WI}<10=$ Tidak Berpotensi (aman)

- $10<\mathrm{WI}<12$ = Potensi Rendah (hijau)

- $12<\mathrm{WI}<23$ = Potensi Sedang (kuning)

Hasil dari proses simplifikasi dengan metode interpretasi manual (digitasi on screen) dapat dilihat pada Gambar 12 sampai dengan Gambar 15. Peta bahaya banjir ditampilkan per pulau besar dalam Kabupaten Banggai Laut.

Salah satu validasi hasil komputerisasi perhitungan raster indeks TWI dengan kenyataan di lapangan diantaranya dibuktikan pada Gambar 16. Pada gambar ini dicocokkan antara klasifikasi indeks TWI berpotensi sedang dengan lokasi histori kejadian banjir di Desa Lompio.Titik lokasi histori kejadian banjir tepat berada pada area aliran warna merah dengan TWI antara 12 sampai dengan 23 (potensi ancaman bahaya banjir sedang). 


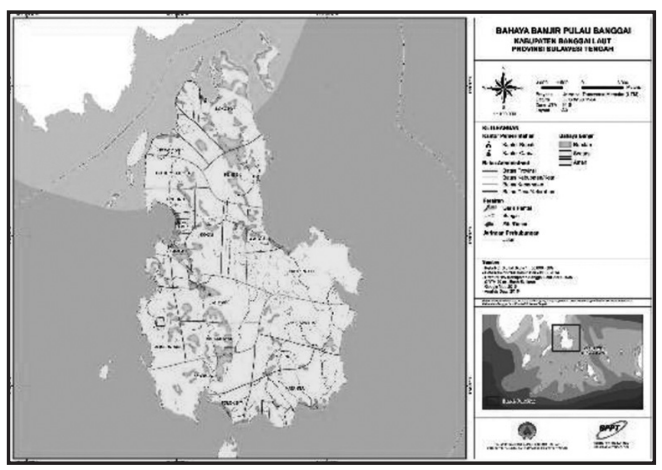

Gambar 12. Peta bahaya banjir Pulau Banggai di Kabupaten Banggai Laut. (Sumber: Hasil pengolahan data, 2016).

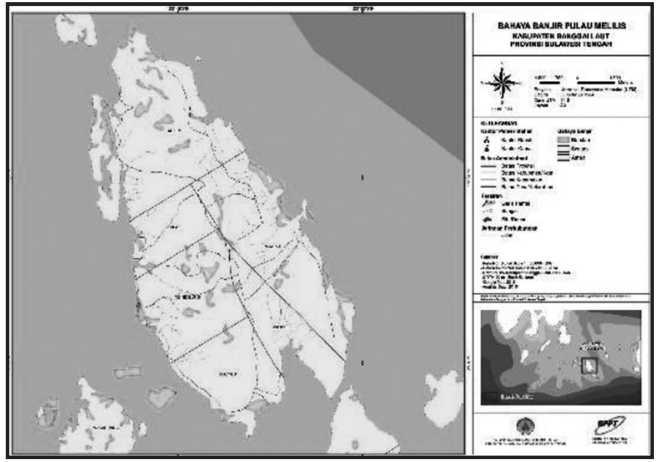

Gambar 13. Peta bahaya banjir Pulau Melilis di Kabupaten Banggai Laut.

(Sumber: Hasil pengolahan data, 2016).

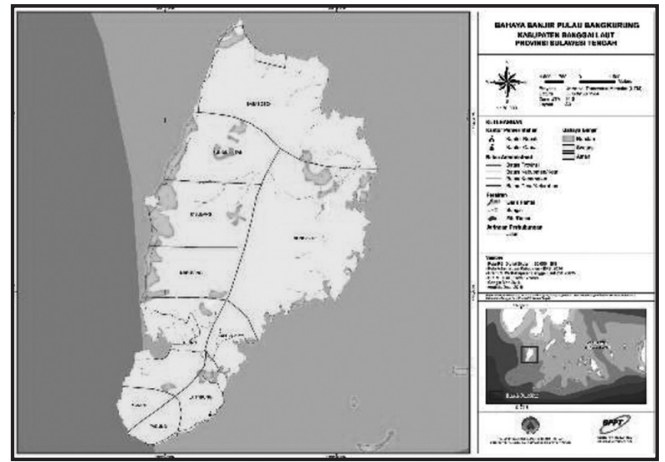

Gambar 14. Peta bahaya banjir Pulau Bangkurung di Kabupaten Banggai Laut.

(Sumber: Hasil pengolahan data, 2016).

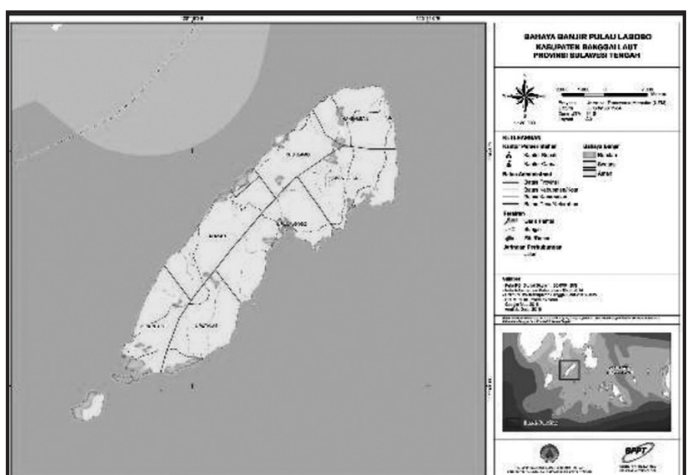

Gambar 15. Peta bahaya banjir Pulau Labobo di Kabupaten Banggai Laut.

(Sumber: Hasil pengolahan data, 2016).

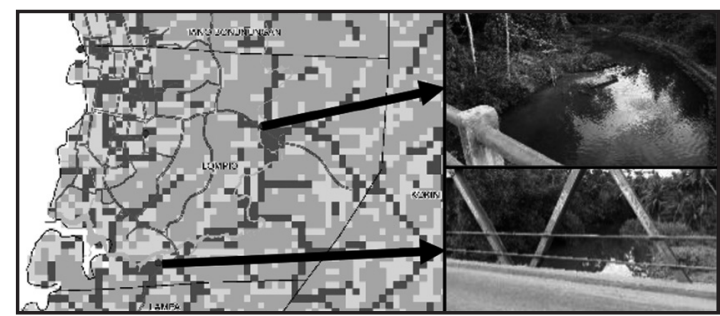

Gambar 16. Contoh hasil validasi indeks kebasahan (TWI) dengan pengamatan lapang 2016.

Banjir di Desa Lompio disebabkan oleh luapan air Sungai Mampaliasan. Sungai Mampaliasan ini menerima air dari Sungai Paisupuso yang terdapat di Desa Kokini. Berdasarkan pengamatan lapangan tahun 2016, area terdampak banjir akibat luapan Sungai Mampaliasan dikarenakan penataan kawasan permukiman sekitar Sungai Mampaliasan tidak benar. Banyak pemukiman yang terletak di area sempadan Sungai Mampaliasan (Gambar 17).

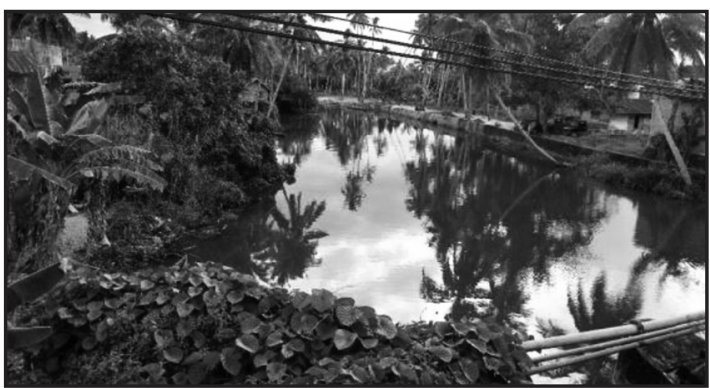




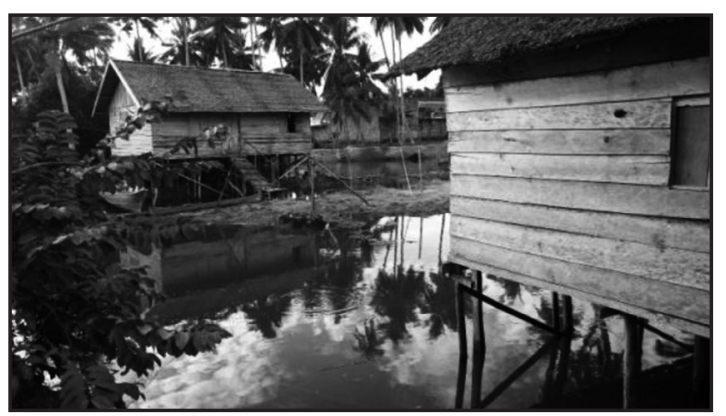

Gambar 17. Aktivitas manusia dan pemukiman di sempadan Sungai Mampaliasan, Desa Lompio, Kecamatan Banggai.

Bahkan SPBU terletak kurang lebih 100 meter dari sempadan Sungai Mampaliasan dan berada di area cekungan (Gambar 18). Potensi risiko banjir pada area ini sangat tinggi. Di area ini, banjir juga disebabkan oleh tidak terdapatnya sistem drainase yang tidak baik serta upaya pencegahan berupa pembuatan tanggul yang masih terlalu pendek (Gambar 19).

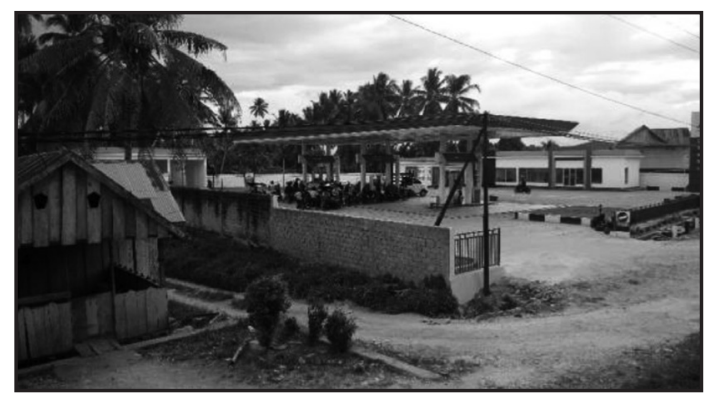

Gambar 18. SPBU yang terletak sekitar 100 meter dari Sungai Mampaliasan.

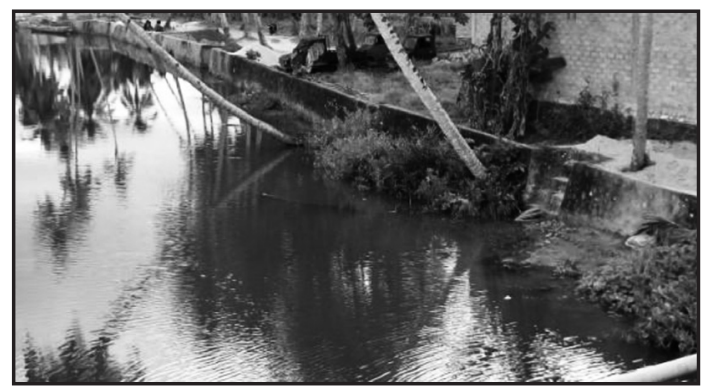

Gambar 19. Tanggul Sungai Mampaliasan di Desa Lompio.
Pada Pulau Melilis Kecamatan Bokan Kepalauan, hasil pengamatan lapang, nampak banjir bahaya rendah (warna kuning) dan bahaya sedang (warna merah) pada muara sungai (Gambar 20). Dari gambar tersebut terlihat bahwa pemukiman terletak dekat sekali dengan muara sungai tersebut. Dikarenakan masih banyak lahan kosong, pemindahan beberapa bangunan pemukiman ke lokasi yang agak jauh dari sungai menjadi salah satu solusi di area ini untuk mengurangi risiko.

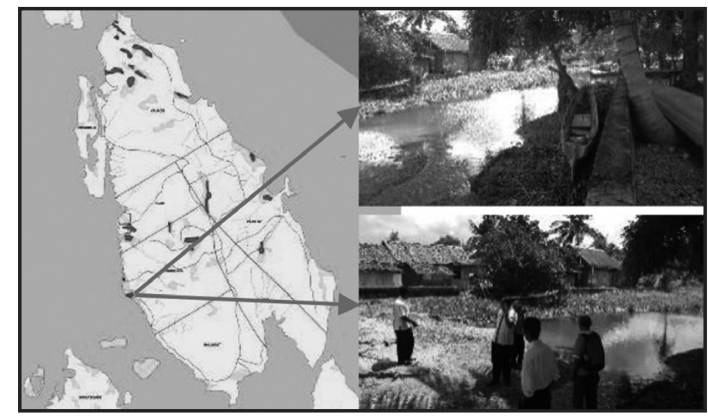

Gambar 20. Gambar Lokasi banjir bahaya rendah pada muara sungai Desa Ndidibung.

(Sumber: Pengamatan Lapang 2016).

Berdasarkan hasil analisis spasial pada Tabel 1, maka desa di Kabupaten Banggai Laut yang memiliki luas area potensi tertinggi bahaya banjir pada kelas sedang adalah Desa Lokotoy, Kecamatan Banggai Utara. Diprediksi memiliki potensi ancaman bahaya banjir sedang seluas $1,93 \mathrm{~km}^{2}$ dan memiliki potensi ancaman bahaya banjir rendah seluas $7,45 \mathrm{~km}^{2}$. Hal ini perlu menjadi perhatian pemerintah daerah Kabupaten Banggai Laut, dikarenakan di Desa Lokotoy ini direncanakan dalam RTRW (Rencana Tata Ruang Wilayah) Kabupaten Banggai Laut untuk dibangun bandara dan pelabuhan rakyat. Meskipun lokasi bandara dan pelabuhan rakyat ini tidak tepat di area bahaya banjir, namun akses dan pengembangan wilayah sekitar bandara dan pelabuhan rakyat ini akan terhambat jika potensi ini tidak diperhitungkan dalam pembangunan kelak. 
Tabel 1. Potensi bahaya banjir beserta luasannya pada desa-desa di Kabupaten Banggai Laut.

\begin{tabular}{|c|c|c|c|}
\hline \multirow{2}{*}{ Desa } & \multicolumn{3}{|c|}{$\begin{array}{l}\text { Luas Bahaya Banjir } \\
\text { (Km persegi) }\end{array}$} \\
\hline & Aman & Rendah & Sedang \\
\hline Kec. Banggai & 72.23 & 7.61 & 2.11 \\
\hline DANGKALAN & 8.55 & 0.93 & 0.60 \\
\hline DODUNG & 5.16 & 0.58 & \\
\hline KOKINI & 11.46 & 1.63 & 0.80 \\
\hline LAMBAKO & 4.08 & 1.47 & 0.03 \\
\hline LAMPA & 1.11 & 1.54 & 0.07 \\
\hline LOMPIO & 0.80 & 0.44 & 0.23 \\
\hline PASIR PUTIH & 29.46 & 0.24 & \\
\hline POTIL POLOLOBA & 10.11 & 0.64 & 0.26 \\
\hline TANO BONUNUNGAN & 0.53 & 0.14 & 0.12 \\
\hline TINAKIN LAUT & 0.96 & & \\
\hline Kec. Banggai Selatan & 78.40 & 5.85 & 1.49 \\
\hline BENTEAN & 18.72 & 2.28 & 0.91 \\
\hline KELAPA LIMA & 19.88 & 0.95 & 0.29 \\
\hline LABUAN KAPELAK & 1.26 & & \\
\hline MALINO & 9.05 & 0.76 & \\
\hline MATANGA & 21.20 & 1.14 & 0.29 \\
\hline TOLOKIBIT & 8.28 & 0.72 & \\
\hline Kec. Banggai Tengah & 43.64 & 8.22 & 3.11 \\
\hline ADEAN & 15.29 & 2.84 & 0.58 \\
\hline BADUMPAYAN & 8.88 & 2.47 & 1.59 \\
\hline GONG-GONG & 2.85 & 0.98 & \\
\hline MOMINIT & 0.47 & 0.34 & 0.34 \\
\hline MONSONGAN & 13.47 & 1.04 & 0.59 \\
\hline POSOSLALONGO & 0.36 & & \\
\hline TIMBONG & 2.23 & 0.25 & \\
\hline TINTINGO & 0.11 & 0.29 & \\
\hline Kec. Banggai Utara & 40.84 & 12.55 & 2.56 \\
\hline BONE BARU & 5.27 & 0.57 & \\
\hline KENDEK & 12.58 & 3.44 & 0.63 \\
\hline LOKOTOY & 13.69 & 7.45 & 1.93 \\
\hline PAISUMOSONI & 2.76 & 0.53 & \\
\hline POPISI & 1.12 & & \\
\hline TOLISE TUBONO & 5.42 & 0.57 & \\
\hline Kec. Bangkurung & 100.80 & 11.37 & 1.25 \\
\hline BONE-BONE & 28.38 & 1.44 & 0.37 \\
\hline
\end{tabular}

\begin{tabular}{|c|c|c|c|}
\hline BUNGIN LUEAN & 9.28 & 1.69 & 0.15 \\
\hline DUNGKEAN & 0.60 & & \\
\hline KALUPAPI & 3.96 & 0.08 & \\
\hline KANARI & 2.67 & 0.00 & \\
\hline LALONG & 10.51 & 0.46 & 0.18 \\
\hline LANTIBUNG & 3.66 & 1.17 & 0.10 \\
\hline MBELEANG & 7.24 & 1.35 & 0.01 \\
\hline SASABOBOK & 22.18 & 1.24 & 0.30 \\
\hline TABULANG & 9.66 & 2.41 & 0.14 \\
\hline TADUNO & 2.66 & & \\
\hline Kec. Bokan Kepulauan & 171.82 & 67.46 & 4.97 \\
\hline BOLOKUT & 10.62 & 0.57 & \\
\hline BUNGIN & 0.24 & 0.11 & 0.04 \\
\hline KASUARI & 12.41 & 0.73 & 0.11 \\
\hline KAUKES & 23.75 & 1.83 & 0.68 \\
\hline KEAK & 6.22 & 0.20 & 0.12 \\
\hline KOKUDANG & 8.32 & 2.32 & 0.37 \\
\hline MANDEL & 8.97 & 0.08 & \\
\hline MBUANG-MBUANG & 16.55 & 3.83 & 0.41 \\
\hline MINANGA & 13.20 & 4.13 & 0.61 \\
\hline NDINDIBUNG & 12.62 & 1.52 & 0.20 \\
\hline NGGASUANG & 10.85 & 19.72 & 0.07 \\
\hline PAISUBEBE & 1.36 & 0.57 & \\
\hline PANAPAT & 26.35 & 2.52 & 0.39 \\
\hline SONIT & 3.21 & 9.80 & 0.73 \\
\hline TIMPAUS & 2.67 & 3.60 & 0.56 \\
\hline TOGONG SAGU & 3.23 & 0.56 & \\
\hline TOROPOT & 11.01 & 4.70 & 0.70 \\
\hline Kec. Labobo & 65.47 & 4.63 & 1.05 \\
\hline ALASAN & 10.96 & 0.38 & 0.08 \\
\hline BONTOSI & 7.97 & 1.67 & 0.21 \\
\hline DESA LALONG & 11.14 & 0.35 & 0.11 \\
\hline LIPULALONGO & 11.26 & 0.47 & 0.15 \\
\hline LIPUTALAS & 8.82 & 0.58 & 0.11 \\
\hline MANSALEAN & 8.22 & 0.37 & 0.19 \\
\hline PADINGKIAN & 0.33 & 0.39 & 0.02 \\
\hline PAISULAMO & 6.75 & 0.42 & 0.18 \\
\hline Total & 573.23 & 117.63 & 16.48 \\
\hline
\end{tabular}

(Sumber : Pengolahan data, 2016). 
Secara umum, Kabupaten Banggai Laut memiliki potensi bahaya banjir kelas sedang seluas $16,48 \mathrm{~km}^{2}$ dan potensi bahaya banjir kelas rendah seluas $117,63 \mathrm{~km}^{2}$. Potensi banjir di Kabupaten Banggai Laut ini, disebabkan karena bentuk morfologi. Tutupan lahan yang relatif sejenis membut koefisien runoff-nya relatif sama. Tingkat curah hujan tahunan kecil. Keadaan geologi jenis batuan karst dan gamping membuat tingkat infiltrasi air hujan menjadi tinggi. Sungaisungai tidak terlalu besar dan sangat jarang, karena diduga terdapat sungai-sungai bawah tanah akibat jenis batuan pada wilayah ini. Halhal inilah yang menyebabkan aliran permukaan menjadi relatif kecil. Sehingga sangat wajar jika tidak ada potensi banjir tinggi pada wilayah ini. Ancaman tetap ada namun kelasnya sedang maupun rendah.

Morfologi memainkan peranan penting pada pembentukan area banjir pada kabupaten ini. Sehingga penanganan pada kawasankawasan cekungan dan tempat berkumpulnya aliran permukan yang terdapat pemukiman warga perlu dilakukan pembuatan drainase yang baik. Drainase yang memungkinkan untuk air mengalir ketempat yang lebih rendah. Drainase yang dibangun tidak perlu memiliki kapasitas tampung air yang besar karena debit maksimal yang terajadi juga tidak akan besar.

Selain pembuatan drainase, program pengurangan risiko bahaya banjir juga perlu dilakukan pemerintah daerah, diantaranya : pembuatan peta risiko bencana abrasi dan gelombang pasang; penyusunan masterplan wilayah DAS dan Sub DAS; pembuatan dan penerapan peraturan daerah (perda) zonasi kawasan sempadan sungai; pengoptimalan sungai, jaringan irigasi, drainase ataupun selokan; pengerukan sampah atau sedimentasi saluran dan kali atau sungai; melaksanakan program tebang pilih dan reboisasi; mempergunakan alat pendeteksi banjir; penyiapan lokasi evakuasi dan jalur-jalur evakuasi bencana banjir.

\section{KESIMPULAN DAN SARAN}

- Kabupaten Banggai Laut tidak memiliki potensi bahaya banjir kelas tinggi.
- Faktor yang diduga paling mempengaruhi bahaya banjir di Kabupaten Banggai Laut ini adalah topografi dan bentuk muka bumi (morfologi) wilayahnya.

- Metode indeks kebasahan untuk identifikasi area banjir cukup akurat untuk diterapkan pada wilayah dengan karakteristik fisik wilayah yang banyak keseragaman serta ketersediaan data yang sangat terbatas.

- Kabupaten Banggai Laut memiliki potensi bahaya banjir kelas sedang seluas $16,50 \mathrm{~km}^{2}$ dan potensi bahaya banjir kelas rendah seluas 117,65 km².

- Desa di Kabupaten Banggai Laut yang memiliki luas area potensi tertinggi bahaya banjir pada kelas sedang adalah Desa Lokotoy, Kecamatan Banggai Utara. Diprediksi memiliki potensi ancaman bahaya banjir sedang seluas $1,93 \mathrm{~km}^{2}$ dan memiliki potensi ancaman bahaya banjir rendah seluas $7,45 \mathrm{~km}^{2}$.

\section{DAFTAR PUSTAKA}

Bappeda Kabupaten Banggai Laut, 2015, Draft RTRW Kabupaten Banggai Laut 20152035.

El-Sheimy, N., 1999, Digital Terrain Model. Department of Geomatics Engineering. The University of Calgary.

Meijerink et al, 1994, Introduction to the use of Geographic Information Systems for Practical Hydrology. Enschede, The Netherlands : International Institute for Aerospace Survey and Earth Sciences (ITC).

Pawitan H., 2004, Perubahan Penggunaan Lahan dan Pengaruhnya Terhadap Hidrologi Daerah Aliran Sungai (Land Use Changes and Their Impacts on Watershed Hydrology). Bogor: Laboratorium Hidrometeorologi FMIPA-IPB. 
Prahasta, E., 2008, Model Permukaan Dijital. Pengolahan Data DTM (Digital Terrain Model) dan DEM (Digital Elevation Model) Dengan Perangkat Lunak : Surfer, Global Mapper dan Quickgrid. Penerbit Informatika Bandung. 537 halaman.

Putra, E. H., 2007, Menentukan Lokasi Daerah Rawan Banjir (Studi Kasus propinsi Sulawesi Utara) Menggunakan Metode TWI. Pengendali Ekosistem Hutan.

Suparta, W., 2004, Kajian Banjir Kota Denpasar Studi Kasus Saluran Drainase Sistem IV Kota baDenpasar. Denpasar : Program Studi Magister IImu Lingkungan Program Pasca Sarjana, Universitas Udayana.
Undang Undang Republik Indonesia Nomor 24 Tahun 2007 Tentang Penanggulangan Bencana. 2015, Laporan Kegiatan Perencaaan Pengelolaan Sumber Daya Alam Kabupaten Daerah Tertinggal, BPPT, Jakarta.

http://geospasial.bnpb.go.id/category/petatematik/banjir/ 